\title{
Sacred Tree as an Archaic Motif in Kyrgyz Epic
}

\author{
Gulina Zhamgyrchieva1, Nelia Bekmukhamedova², Makhbubakhon Temirova ${ }^{3}$, \\ Kyzburak Madanova ${ }^{4}$, Mekhrinsa Sulaymanova $^{3}$, Nazgul Takhirova ${ }^{1}$, Altynai Ermatova ${ }^{5}$, \\ Aikanysh Zhumabaeva ${ }^{6}$, Zhypargul Abdullaeva ${ }^{7 *}$ (1)
}

\author{
${ }^{1}$ Department of Kyrgyz Literature, Osh State University, Osh, Kyrgyzstan \\ ${ }^{2}$ Department of the Russian Language and Literature Teaching and Methodics, Osh State University, Osh, Kyrgyzstan \\ ${ }^{3}$ Department of the Russian Language and Literature, Andijan State University, Andijan, Uzbekistan \\ ${ }^{4}$ Department of Practical Course of Kyrgyz Literature and Literature, Osh State University, Osh, Kyrgyzstan \\ ${ }^{5}$ Department of Languages, Zhalal-Abad State University, Zhalal-Abad, Kyrgyzstan \\ ${ }^{6}$ A. Khalmurzhaev Secondary School, Uzgen Region, Kyrgyzstan \\ ${ }^{7}$ Science and Research Department, Osh State University, Osh, Kyrgyzstan \\ Email: ^jypar.science@oshsu.kg
}

How to cite this paper: Zhamgyrchieva, G., Bekmukhamedova, N., Temirova, M., Madanova, K., Sulaymanova, M., Takhirova, N., Ermatova, A., Zhumabaeva, A., \& Abdullaeva, Z. (2020). Sacred Tree as an Archaic Motif in Kyrgyz Epic. Open Journal of Modern Linguistics, 10, 834-839. https://doi.org/10.4236/ojml.2020.106053

Received: November 19, 2020

Accepted: December 12, 2020

Published: December 15, 2020

Copyright $\odot 2020$ by author(s) and Scientific Research Publishing Inc. This work is licensed under the Creative Commons Attribution International License (CC BY 4.0).

http://creativecommons.org/licenses/by/4.0/

\begin{abstract}
This article is investigating archaic motif of the saint tree in the Kyrgyz epic through a comparison of world folklore materials. This research aims to show an artistic image of archaic motifs in the Kyrgyz epic in mythological and poetic contexts. Objectives of the study were to determine formation and development of epic, the role of archaic motifs by using the comparative-typological methods in the folklore study. Research results are useful for the folklore studies in the philological aspect, particularly in the epic studies. The relevance of the chosen topic is associated with the study of ancient poems and folk works from the modern point of view, and the concept of human values through the prism of folklore heritage.
\end{abstract}

\section{Keywords}

Archaic Motifs, Folklore, Ancient Worldview, Sacred Tree, Epic

\section{Introduction}

The term sacred tree is widespread in mythology and folklore of people around the world (Gilmore, 2016). The various definitions of term "sacred tree" may be classified according to four groups of criteria: 1) natural elements: the physical characters of the tree; 2) supernatural elements believed to reside in the tree and act upon humans; 3) human ritual behaviors related to the trees and 4) botanical criteria such as high biodiversity (Dafni, 2006).

The ancient mythical and poetical representations of people about the 
three-stage structure of the world were found in many nations. Reflection of the three-dimensional world in the Kyrgyz epic is based on the cosmogonic and mythical perception. In the epos "Manas" and "Er Toshtuk" in mythological and poetical understanding three-dimensional worlds consisting of underground, above-ground, and the world of sky are linked by a tree. For example, in epos "Manas" this tree is named as Baiterek, and in the epos "Er Toshtuk" it is called a Chukterek. The theme of the holy (Kandari et al., 2014) tree is widespread in world mythology, which is a reflection of human creativity, used in the modern science in a terminological context (Ökten, 2016).

In the worldview of an ancient man, a mythical tree is regarded as a kind of model of the world. It is like a pillar of the world that serves as a link between man and the universe. The Kyrgyz epos "Manas" is containing descriptions of the sacred tree Baiterek. According to ancient mythical thinking, it integrates three stages of the universe: the upper, middle, and lower worlds. Every image of the hero Manas was personified by the sacred tree (Aiptaeva, 2013). It also brings together the worlds, countries and people (Fraser, 1980).

\section{Research Methods}

In this work, comparative typological and contrasting methods were used based on the Kyrgyz epics "Manas", "Er Toshtuk" and other nation's epics.

\section{Results and Discussions}

The mythological and poetic models of the world were restored based on a variety of sources from paleontology and biology data, from the information of contemporary archaic groups on ethnography, surviving representation of the consciousness of modern man, from the data relating to language, the symbolism of dreams and deeper areas of unconscious and artistic creativity, etc., in which archaic structures (including the archetypes) can be detected and reconstructed.

According to this, if the image of hero Manas is conveyed in comparative terms with the sacred tree, then the image archetypical of Baiterek in the truest sense of the ancient world view was described as a combining three-stage world as living center of the universe.

As it is known, there have been created many versions of the sacred tree images in mythology and folklore of the world, including religious mythology that has been given a lot of attention. "From the trees primarily bodhi tree (enlightenment) came into Buddhist mythology, used at various intellectual levels to give symbolic and sometimes quasi-historical expression to religious teachings" (Sponsel \& Natadecha-Sponsel, 2014; Britannica Encyclopedia, 2019). It is a real-life kind of representative of ficus religiosa (Singh et al., 2014), under which Sakyamuni, according to the Buddhist myth, attained enlightenment (bodhi). Bodhi tree becomes an essential attribute of the entire Buddhas world. But Buddhist mythology knows purely mythological trees too that are first of all the 
so-called kalpavrikshas that are found on all four continents and throughout the entire kalpa. Chittapatali tree grows in the kingdom of asuras. It is the object of contention between the asuras and the gods, for because of the great height of the tree its fruits accrue only to the gods. In general, the archaic belief and worship of a lone tree, tying pieces of cloth to its branches are one of the ancient rituals of the Kyrgyz people, and which at this time does not lose its strength and used in ceremonies of the worship of holy places. All this emerged from the archaic belief in the minds of ethnic groups on the cleansing and performing power of the plant. In this case, the image of a tree originates from ancient times. According to the ancient notion about the tree, except for the role of three pillars of worlds, the tree has the character of a fruiting, feeding people and animals, including birds.

In the second parts of the epics "Manas" and "Semetei", the Manas's wife Kanykei flees from the enemy to Bukhara with her baby in her hands after the death of spouse, and on the way she was tired and stopped under the Baiterek tree to rest. She speaks to Baiterek tree to support her, take care, feed, and serve for her as a parent, and in the difficult times she can count on it (Karalaev, 1986; Sarypbekov, 1987). After Kanykeis request, the tree Baiterek gives milk from its branches through the leaves, and refugees shall be filled and resting on the shadow of a huge tree after a long journey. Here we see the creation of an ancient man, a mythological and poetical image of the world, tree as the mother and protector of all living things. As in the Kyrgyz epic, the Greek mythology gives the image of a sacred tree-oak, under which Zeus grew himself, later this tree was considered as the symbol of Zeus.

\section{Researchers Interpretation}

English ethnographer and religionist researcher J. Frazer wrote in his book "The Golden Bough" an interesting example of the Kyrgyz ceremonies: "To conceive a child a Kara-Kyrgyz barren woman is rolling on the ground under a lone apple tree". According to this, a fruit tree, as the archetype of the mother in the popular understanding, represents the birth of life, hence the unity of humankind and nature.

Researcher Robert Sarypbekov mentioned in the Turkic-Mongolian epic that a miraculous tree is not alone; it is in unity with other totemistic forces takes the effect mentioned above. Especially a variety of zoomorphic and anthropomorphic animals living inside it and adherent were highlighted. In Khakassia and Sakha epic images of the Aan-Alahchyn Khotun, Huu-Inei can be considered as a glaring example of this. In the evolution of the Kyrgyz epic "Manas", these archaic motifs and images in a long process of oral transformation have been forgotten or moved into real images, for example, images of real animals and birds (Sarypbekov, 1987).

In another Kyrgyz epic "Er Toshtuk" the mythical elements have been brightly saved, and characterized by the antiquity of its foundation, the main character, 
going down into the underworld, controlling seven prizes of the khan of dungeons of the mythical hero Kekde, gets married to his daughter Kyulyaim. Toshtuk overcomes other hero giants, such as Choyun fist, and with the help of a giant bird living in the tree, Chukterek is raised to the middle world. And here Chukterek, like Baiterek mentioned above was described as a pillar of the world and as the fruit-bearing, nursing tree which sheltered a lot of birds and animals as shown in Figure 1.

E. Yamaeva stated that, in the global three-membered (upper, middle, lower) worlds model the "black stump" is a mediation element between the three spheres of the universe as represented in Figure 2.

"Black stump" was identified with the world tree or world pole being a "substitute" to the mediation element symbolizing the "axis of the world". It adds to

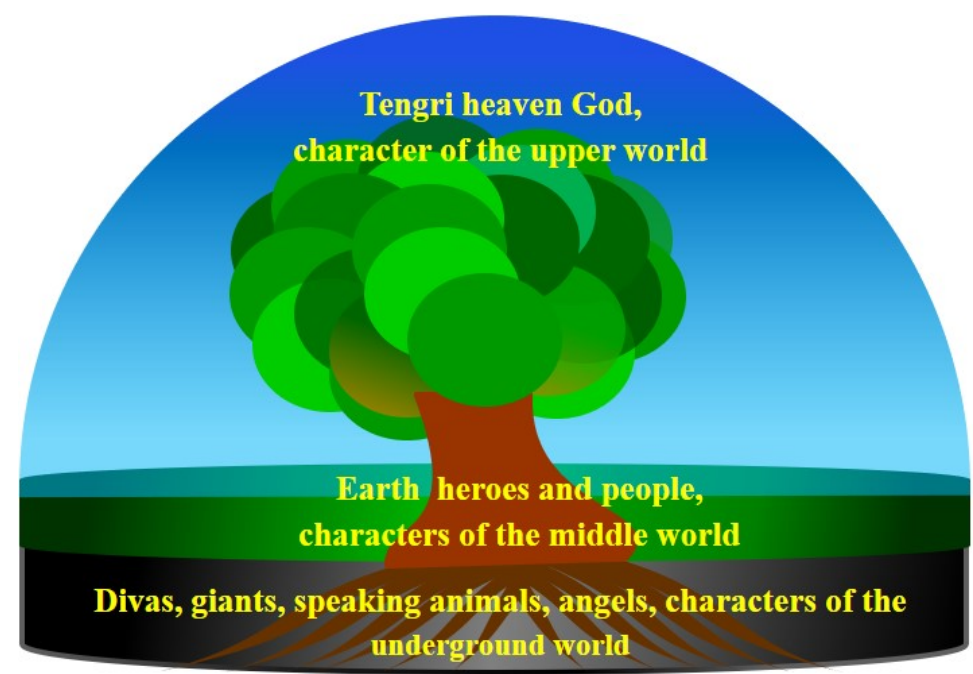

Figure 1. The ancient concept of a three-stage world in Kyrgyz folklore (epic "Er Toshtuk").

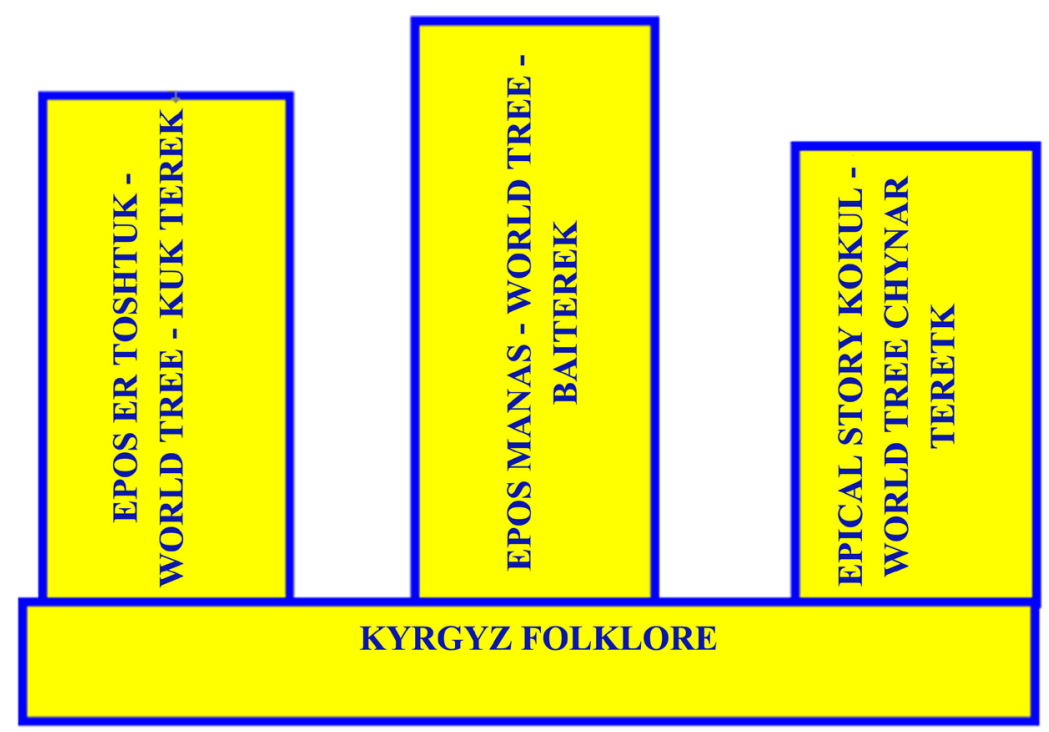

Figure 2. World tree in Kyrgyz folklore. 
our noted above opinion of the world tree. The idea of the world tree and its place in the universe has firmly settled in the mythical consciousness of humanity, in global myth making and folklore of many nations. This idea has a central place in the Kyrgyz epic.

\section{Conclusion}

In summary, it can be noted that a stable place of an archaic motif of the world tree in the Kyrgyz epic indicates the antiquity of mythological and poetical thinking of an ethnic group; it was established and was common in the same story in the world of mythology and folk genres. The world tree motif and the history of other cultures, as well as in the Kyrgyz epics, take back to mythology in the folklore plan reflecting the mythological worldview of people, and have been saved in the typological similarity with the Turkish-Mongolian epics. This motif is a valuable folklore heritage, containing a wealth of archaic materials, and has found its reflection in the Kyrgyz epics, and its in-depth study undoubtedly opens up new perspectives in the epics research generally.

Practical implications in this work can be used in teaching the folklore studies in higher and secondary education; and in the cognitive plan can be useful for society learning individuals folklore works.

\section{Conflicts of Interest}

The authors declare no conflicts of interest regarding the publication of this paper.

\section{References}

Aiptaeva, G. (2013). Sacred Site of the Southern Kyrgyzstan: Nature, Manas and Islam (240 p). Bishkek: Aigine Cultural Research Center.

Britannica Encyclopedia (2019). https://www.britannica.com/topic/Buddhism/Mythology

Dafni, A. (2006). On the Typology and the Worship Status of Sacred Trees with a Special Reference to the Middle East. Journal of Ethnobiology and Ethnomedicine, 2, Article No. 26. https://doi.org/10.1186/1746-4269-2-26

Fraser, J. (1980). The Golden Bough (831 p). Moscow: Political Literature Publishing House.

Gilmore, A. (2016). Trees as a Central Theme in Norse Mythology and Culture: An Archaeological Perspective. Scandinavian-Canadian Journal, 23, 16-26.

Kandari, L. S., Bisht, V. K., Bhardwaj, M., \& Thakur, A. K. (2014). Conservation and Management of Sacred Groves, Myths and Beliefs of Tribal Communities: A Case Study from North-India. Environmental Systems Research, 3, Article No. 16. https://doi.org/10.1186/s40068-014-0016-8

Karalaev, S. (1986). Manas Epic (262 p). Frunze: Kyrgyzstan.

Ökten, A. I. (2016). Mythology and Neurosurgery. World Neurosurgery, 90, 315-321. https://doi.org/10.1016/j.wneu.2016.02.106

Sarypbekov, R. (1987). Evolution of Heroic Motifs in the Epic "Manas" (151 p). Frunze: Ilim.

Singh, P., Singh, D., \& Goel, R. K. (2014). Ficus religiosa L. Figs-A Potential Herbal Ad- 
juvant to Phenytoin for Improved Management of Epilepsy and Associated Behavioral Comorbidities. Epilepsy \& Behavior, 41, 171-178.

https://doi.org/10.1016/j.yebeh.2014.10.002

Sponsel, L. E., \& Natadecha-Sponsel, P. (2014). Buddhism and Ecology. In D. A. Leeming (Ed.), Encyclopaedia of Psychology and Religion. Boston, MA: Springer.

https://doi.org/10.1007/978-1-4614-6086-2_9296 